Marina MATIĆ BOŠKOVIĆ, PhD*

Research Fellow

Institute of Criminological and

Sociological Research
Review paper

Received: 7 November 2021

Accepted: 26 November 2021

UDK: 341.44\%.45(4-672EU)

004.6:343.13

https://doi.org/10.47152/rkkp.59.3.6

\title{
IMPACT OF MODERN TECHNOLOGIES ON FREE MOVEMENT OF EVIDENCE IN EUROPEAN UNION
}

According to the estimate of the EU Commission 85 percent of criminal investigations require electronic evidence, while in almost two thirds (65 percent) of the investigations where e-evidence is relevant. Investigation and prosecution of crime increasingly relies on the possibility to have access to data held by service providers, as private company. Modern criminal investigation and use of electronic evidence imposes challenges to the right to fair trial and rule of law standards.

The paper identifies benefits and challenges of proposed EU instruments for facilitating e-evidence. The European Commission proposed Regulation of Production Order and Preservation Order with the aim to facilitate access to relevant data stored by service providers. The paper recognizes shortcomings of the proposed Regulation. The biggest challenge is lack of judicial oversight of orders, as a guarantee of fair trial. The paper includes recommendations and policy options for promoting judicial system for cross border access and collection of electronic data in line with EU fundamental rights standards.

Key words: mutual legal assistance, EU acquis, digital evidence, legal remedy, production and preservation order

* E-mail: m.m.boskovic@roldevelopmentlab.com 


\section{Introduction}

The EU member states have cooperated in criminal matters for several decades. However, until the entry into force of the Maastricht Treaty in 1993, cooperation in criminal matters stood completely outside the EU Treaties (Willems, 2021: p. 33). Cooperation initially took place under the auspice of the Council of Europe and relevant international instruments. ${ }^{1}$ Nevertheless, within the European Union initiatives were taken to regulate cooperation in criminal matters with the EU acquis. Already, signing of Schengen Treaties in $1985^{2}$ led to creation of favorable environment while the Lisbon Treaty signed in 2007 changed the whole framework by Article 67 of the Treaty on Functioning of the EU. Article 67 states that the EU shall constitute an area of freedom, security and justice through measures to prevent and combat crime and encourage coordination and cooperation between police and judicial authorities in criminal matters. Furthermore, the Article 82(1) of the Treaty on Functioning of the EU stipulates that judicial cooperation in criminal matters shall be based on the principle of mutual recognition and should include the harmonization of the legislative framework of the Member States in criminal matters having a cross-border dimension (Herlin-Karnell, 2012: 34).

The principle of mutual recognition is defined by the European Commission in the Communication on Mutual Recognition of Final Decision in Criminal Matters as being based on the idea that another State may not deal with a certain matter in the same or even a similar way as one's own State, the results will be such that they are accepted as equivalent to decisions by one's own State. ${ }^{3}$ Provided definition reflects EU Member States agreement to promote judicial cooperation by not requiring to change national criminal laws, but only to accept judicial decisions originating from other Member States (Mitsilegas, 2006: 279)

To the mutual recognition has been referred to as cornerstone of judicial cooperation in criminal matters by EU institutions, ${ }^{4}$ including Court of Justice of

1 Council of Europe, European Convention on Mutual Assistance in Criminal Matters, 1959, https:// www.coe.int/en/web/conventions/full-list/-/conventions/treaty/030?module=treaty-detail\& treatynum $=030$

2 The Schengen Acquis - Convention Implementing the Schengen Agreement of 14 June 1985 between the Governments of the States of the Benelux Economic Union, the Federal Republic of Germany and the French Republic on the Gradual Abolition of Checks at Their Common Borders, Official Journal L 239, 22.09.2000.

3 Commission of the European Communities (2000): Mutual Recognition of Final Decisions in Criminal Matters, Communication from the Commission to the Council and the European Parliament, COM(1999) 495 final.

4 Point 35 of the Tampere conclusions. See: European Council (1999): 'Presidency Conclusions, Tampere European Council 15th-16th October 1999, European Council. 
the European Union. ${ }^{5}$ The objective of mutual recognition is to remove the possibility of political involvement and to avoid a second examination as to the substantive merits of the case (Klimek, 2017: 9). It may be possible to verify that a decision has been taken by an authority in another Member State, but the merits of that decision should not be reviewed.

To enable application of the mutual recognition principle in judicial cooperation in criminal matters, the Member States agreed to develop and adopt specific measures that concerns all stages of the criminal process (Mitsilegas, 2016: 126). The first instrument was European Arrest Warrant, leading to mutual recognition in extradition. ${ }^{6}$ Other instruments have been adopted on execution of freezing and confiscation orders, ${ }^{7}$ bail decisions,${ }^{8}$ enforcement of financial penalties, ${ }^{9}$ recognition of probation orders and alternative sanctions, ${ }^{10}$ custodial sentences ${ }^{11}$ and European Investigation Order. ${ }^{12}$

Existing EU mutual recognition instruments have been designed to balance the principle of effective investigation and prosecution of crime and principle of effective judicial control of investigation authorities' actions (orders/requests). The mutual recognition instruments are based on the high level of trust between EU Member States and strict respect of high standards of individual rights protection in each Member State (Suominen, 2011: 51). These instruments foresee ex ante control by competent judicial authority in the country of issuing of EU instrument and in the country of execution of cross-border request. The aim is to ensure that appropriate legal procedures are followed and supervised by competent oversight bodies (Carrera, Stefan, 2020: 14), namely the EU Member States' judicial authorities. However, the EU Member States' judicial authorities have a duty to recognize and execute criminal justice decision issued by another EU country, only if fundamental rights protection is ensured (Lenaerts, 2017: 809. ${ }^{13}$ In addition, the mutual recognition instruments are based on the premise that the criminal courts

5 Judgment of the Court of Justice of the European Communities of 3rd May 2007, case C-303/05 Advocaten voor de Wereld VZWv Leden van de Ministerraad, para. 4 .

6 Council Framework Decision 2002/584/JHA, OJ L190/1.

7 Regulation 2018/1805, OJ L 303/1.

8 Council Framework Decision 2009/829/JHA, OJ L 294/20.

9 Council Framework Decision 2005/214/JHA, OJ L 76/16.

10 Council Framework Decision 2008/947/JHA, OJ L 337/102.

11 Council Framework Decision 2008/909/JHA, OJ L 327/27.

12 Directive 2014/41/EU, OJ L 130.

13 According to article 1 (3) of the Framework Decision 2002/584 mentioned decision shall not have the effect of modifying the obligation to respect fundamental rights and fundamental legal principles as enshrined in Article 6 of the Treaty on European Union. 
meet the standards of effective judicial protection, which include in particular independence and impartiality of these courts. ${ }^{14}$

The revolution caused by IT is affecting the whole criminal justice system in every country and consequently the instruments of mutual legal assistance in criminal matters. Authorities investigating and prosecuting crime are relying on cross-border data so EU instruments for judicial cooperation in criminal matters provide investigating and prosecuting authorities with possibility to request needed information also in digital form, from competent authorities of another EU Member States (Stefan, Gonzalez, 2018: 8).

According to the estimate of the EU Commission 85 percent of criminal investigations require electronic evidence, while in almost two thirds (65 percent) of the investigations where e-evidence is relevant, a request to service providers across the borders is needed, which is consequence of use of modern technologies in everyday life..$^{15}$

The increasing use of internet and transfer of data in digital form led investigation and prosecution authorities to rely on this information as valuable evidence. Granting law enforcement actors the possibility to efficiently gather different types of electronic data across borders is considered crucial for for the investigation and prosecution of criminal offences.

The aim of the article is to identify how the increasing use of information and telecommunication technologies, and the digitalisation of everyday social and economic interactions, influenced on rules and instruments of the cross-border gathering and exchange of evidence in criminal proceedings.

\section{EU initiatives for modernization of cross-border cooperation in criminal matters}

As part of the modernization efforts the European Commission proposed in April 2018 two legislative documents on gathering of electronic evidence in criminal matters. One proposal relates to the European Production and Preservation Orders for Electronic Evidence in Criminal Matters ${ }^{16}$ and second on harmonizing

14 Case C-216/18 PPU Minister for Justice and Equality v LM, Judgment of 25 July 2018 [ECLI:EU:C:2018:586], para. 79.

15 Commission Staff Working Document - Impact Assessment accompanying the Proposal for a Regulation on European Production and Preservation Orders for electronic evidence in criminal matters and the Proposal for a Directive laying down harmonised rules on the appointment of legal representatives for the purpose of gathering evidence in criminal proceedings, $\operatorname{SWD}(2018)$ 118, p. 14.

16 Proposal for a Regulation of the European Parliament and of the Council on European Production and Preservation Orders for electronic evidence in criminal matters, $\operatorname{COM}(2018) 225$ final. 
rules on the appointment of legal representatives for the purpose of gathering evidence in criminal proceedings. ${ }^{17}$ As terrorist attacks from September 11, 2001 incentivized adoption of European Arrest Warrant, the terrorist attacks in Brussels of 22 March 2016 triggered the Joint Declaration of EU Justice and Home Affairs Ministers and Representatives of EU institution to stress the need to find a approach to obtain more quickly digital evidence by intensifying cooperation with service providers that are active on European territory. Later in 2017 the European Council asked Commission to prepare a legislative proposal. ${ }^{18}$ The available judicial cooperation and mutual assistance instruments are too slow and complex, enabling criminals to resort to new technologies, so new proposal should address existing challenges (Tinoco-Pastrana, 2020: 46). Proposed Regulation and Directive aimed at creating a legal framework allowing law enforcement in one EU Member State to directly request service providers in another Member State to produce or preserve data (Tosza, 2020: 162). Implementation of proposed acts would require new challenges to be created for direct interconnection of investigating and prosecuting authorities and private companies in all EU members states. (Carrera, Mitsilegas, Stefan, 2021: 26).

In addition to legislative documents, the European Commission in July 2020 adopted the EU Security Union Strategy ${ }^{19}$ as a planning document for development of tools and infrastructures necessary for law enforcement and criminal justice practitioners to cooperate and share information. The document noted that use of digital technologies can improve the efficiency of justice system and a key priority should be adopted of proposed Regulation on Production and Preservation Orders. ${ }^{20}$

However, currently, most data exchanges in the EU cross-border judicial cooperation still take place on paper, which is slower and less efficient than using electronic means. The EU initiated increasing the efficiency of EU cross-border judicial cooperation through enhanced digitalisation in criminal matters. The European Commission intends to propose new legislation to make the digital channel the default one for all EU cross-border judicial cooperation communication and

17 Proposal for a Directive of the European Parliament and of the Council laying down harmonized rules on the appointment of legal representatives for the purpose of gathering evidence in criminal proceedings, $\operatorname{COM}(2018) 226$ final.

18 Council Conclusions on the Joint Communication to the European Parliament and the Council: Resilience, Deterrence and Defence: Building strong cybersecurity for the EU, 14435/17, https:// www.consilium.europa.eu/media/31666/st14435en17.pdf

$19 \mathrm{COM} / 2020 / 605$ final.

20 Proposal for a Regulation of the European Parliament and of the Council on European Production and Preservation Orders for electronic evidence in criminal matters COM/2018/225 final 2018/0108 (COD); and Proposal for a Directive of the European Parliament and of the Council laying down harmonised rules on the appointment of legal representatives for the purpose of gathering evidence in criminal proceedings COM/2018/226 final 2018/0107 (COD). 
data exchanges between the competent national authorities, which is presented in the Communication on digitalization of justice in the European Union adopted by the Commission on 2 December 2020. ${ }^{21}$ The European Commission will work on a legislative proposal to digitalize cross-border judicial cooperation procedures in civil, commercial and criminal matter. Furthermore, the fight against serious cross-border crime requires data exchange between Eurojust, Europol and European Public Prosecutor Office. Connection between three criminal justice institutions will ensure knowledge of ongoing investigation and prosecution. The interconnection between EU institutions is the first step, but EU Members States should put efforts to digitalize their registers and enable interconnection.

The EU main IT tool for cross-border cooperation is e-CODEX that enables secure cooperation in civil, commercial and criminal proceedings across borders. Another digital tool that was developed with the aim to facilitate e-evidence digital exchange is eEDES, which ensures swiftly and securely exchange of European Investigation Orders, mutual legal assistance requests and associated evidence in digital format. The key shortcoming that limits use of the eEDES is that not all EU Member States are connect to the tool.

\section{Covid 19 impact on mutual legal assistance in criminal matters}

The COVID-19 pandemic has shown how certain types of modern technologies can play a critical role in ensuring the continued functioning of justice at national and EU level, especially at times of persisting health emergencies and in light of the backlog derived from court lockdowns. To enable functioning of the courts, countries where level of information technology development allowed introduced modalities of online hearings and/or other use of modern technologies during proceedings like electronic filing (Matić Bošković, Nenadić, 2021: 281).

Videoconferencing tools and digital communication systems have allowed courts and justice systems to operate during the health crisis, and by doing so they have contributed to guaranteeing the delivery of key legal safeguards, including the right to judicial control of deprivation of liberty and the right to an effective remedy. In contexts where restrictive and preventive measures are still being adopted to deal with the coronavirus pandemic, these technologies can mitigate the negative effects of health-emergency regimes and address immediate concerns related to access to justice. However, when it comes to the mutual recognition

21 COM/2020/710 final. 
instruments, the EU Member States were facing challenges to implement the European Investigation Order when the hearing by videoconference was requested. ${ }^{22}$ In some Member States, it was possible to conduct hearing by videoconference only in very important and urgent cases. In addition, the national authorities faced serious challenges arising from lack of staff and technical difficulties caused by the pandemic. The COVID-19 measures often meant that trained administrative staff specializing in technical matters were not available on the dates requested by issuing authorities and alternative videoconferencing platforms were used instead of standard ones, which cause additional technical problems.

At the national level the COVID-19 pandemic enhanced the process of digitalization of the justice system. A number of initiatives are being taken ranging from allowing court users to monitor on-line the stages of proceedings to organize on-line hearings. The crisis led to an acceleration of digitalization in criminal trials, where the Prosecution service was granted the possibility to hear witnesses and examine suspect through video conference and appoint experts. ${ }^{23}$

In some EU countries, COVID-19 has led to the introduction of new means to digitally produce or exchange legal documents, including evidence in criminal proceedings. In Italy, for instance, a new 'cloud system' has been created to enable documents from the defence and the prosecutor to be filed and exchanged digitally. In other countries, the COVID-19 crisis has led authorities to introduce new systems for filing documents to the courts or prosecutor's office (either by phone or electronically), or to enable digital access to justice services, for instance by signing documents and exchanging them electronically. ${ }^{24}$

The COVID-19 impacted judicial cooperation in criminal matters. In particular, the pandemic affected the most frequently used instruments of judicial cooperation and posed challenges for practitioners. When it comes to the request for transmission of an European Investigation Order the Member States faced challenges when physical presence of a person was needed, typically for the hearing of witness or a suspect. Although execution of European Investigation Order was still possible, in some Member States were willing to do so only in urgent case. ${ }^{25}$

22 The Impact of COVID-19 on Judicial Cooperation in Criminal Matters - Analysis of Eurojust's Casework, EUROJUST, 2021, p.16

232020 Rule of Law Report - Country chapter on rule of law situation in Italy, SWD(2020) 311 final, p. 5. Information received in the context of the country visit and of the consultation process for the preparation of the report, e.g. Ministry of Justice contribution (an increase of $89 \%$ in videoconferences has been registered in May 2020 with respect to May 2019).

24 European e-Justice Portal, "Digital Tools in Member States".

25 The Impact of COVID-19 on Judicial Cooperation in Criminal Matters - Analysis of Eurojust's Casework, EUROJUST, 2021, p.26. 
Based on the experience during COVID-19 the EUROJUST is calling for the establishment of a single electronic platform for the exchange of the most frequently used tools of judicial cooperation that does not depend on the transmission of hard copies.

\section{European Production and Preservation orders as attempt to regulate digital evidence}

Electronic evidence differs from other evidence causing the current legal framework impractical for law enforcement. The proposed European Production and Preservation Orders have been developed to answer on technological developments and ensure access to the growing need to have access to digital evidence.

Electronic evidence is held on servers owned by service providers who are often foreign, non-EU, companies. Given the market share of major service providers most often these companies are USA legal entities (i.e. Google, Facebook, Microsoft, Apple). The origin of the company is part of the challenge, to the complexity of data gathering can contribute location of servers where data are stored, and which could be in the third country. Investigation and prosecution in cases where electronic evidence is involved, require use of instruments of international legal cooperation, which is time-consuming. ${ }^{26}$ In addition, the territorially-based mutual legal assistance instruments does not work with physical, technological and corporate structures that are used to deliver cloud-based services (Krishnamurthy, 2016: 1). Also, USA Supreme Court judges endorsed the view that US courts are not empowered to issue warrants for foreign searches (Daskal, 2015: 354).

Additional challenge for investigating authorities might be if data are not stored on a single server so requests for access to digital evidence cannot be fulfilled (Frenssen, 2017: 538). The investigation authorities depend much more on cooperation of service providers, not only in the country where their headquarter is, but also where data are stored and where the subsidiaries are located. The courts in EU are trying to overcome this problem through asserting their jurisdiction against headquarter company through their local subsidiaries. The European Court of Justice confirmed as right the approach of Spanish courts to order the search of provider's Californian parent company. ${ }^{27}$ However, the law enforcement authorities are lacking mechanism to obliged service providers to respond on their

26 Non-paper: Progress Report following the Conclusions of the Council of the European Union on Improving Criminal Justice in Cyberspace, 2 December 2016, 15072/16, p 5.

27 Google Spain SL and Google Inc. v. Agencia Española de Protección de Datos (AEPD) and Mario Costeja González, Case C-131/12, ECLI:EU:C:2014:317, para. 43 
requests. The example of the abandoning of territoriality was deliver ${ }^{28} \mathrm{ed}$ by Belgium, first in case law of the Supreme Court in case of Yahoo in 2011, 2012 and 2015 and latter in case against Facebook (De Hert, P., Parlan, C., \& Thumfart, J., 2018: 343). Provisions allowing remote evidence gathering through the internet have been introduced lately in national legislation of Belgium, Germany and Austria. (Warken, 2018: 227)

The European Production and Preservation Orders are design to bring a new dimension in mutual recognition. The European Production Order consists of a binding request that member state investigating, and prosecuting authorities could issue to a service provider offering services in the EU and established or represented in another member state to produce electronic evidence. ${ }^{29}$ The European Preservation Order would instead impose mandatory request to service providers to preserve electronic evidence in view of a subsequent request for production of such data. Both orders may only be issued for criminal proceedings, both during the pre-trial and trial stage. ${ }^{30}$

The proposal is diverging from usual approach of the mutual recognition of judicial decision within the Union and is mainly directed to enabling law enforcement actors to request, access and share data held by service providers across borders.

The proposed regulation should have limited scope and European Production Orders could be issue only for offence capable of attracting a custodial sentence of three years of more, or when the underlying offence falls under one of the definitions adopted under EU instruments regarding money counterfeiting, child sexual abuse, cybercrime and terrorism. ${ }^{31}$ Production Orders targeting subscriber data and access data may be issued for any criminal offence.

The proposed Regulation makes distinction between content data and transactional data on the one hand, and access data and subscriber information on the other. ${ }^{32}$ The proposal foresees that different authorities would be responsible for issuing the orders depending on the type of data sought.

The investigating and prosecuting authorities have main role in issuing production order for subscriber and access data, while judicial authorization in the issuing country would be obligatory when a production order concerns the production transactional or content data. ${ }^{33}$ The validation of production order

28 Yahoo! Inc. v Belgium case, Hof van Cassatie of Belgium, 1 December 2015, case P.13.2082.N.

29 Article 2(1) of the proposed Regulation.

30 Article 3 of the proposed Regulation.

31 Article 5 of the proposed Regulation.

32 Article 2(7)(10) of the proposed Regulation.

33 Article 4 of the proposed Regulation. 
could be done directly by prosecutors. Judicial scrutiny would not be required for subscriber and access data since these categories are perceived as less intrusive and hence do not require the same level of ex ante scrutiny.

Service providers fall into the scope of the draft Regulation only if they are offering services in the EU and are established or represented in another member state. ${ }^{34}$ The proposal introduced the solution that regulation apply to the service providers that offer services in the European Union.

Non-compliance with the order may trigger two types of consequences: sanctions and enforcement procedure. As to the sanctions, the proposed Regulation leaves to the member states to provide necessary rules, However, the Council of the EU in the General approach on the proposal for a Regulation added a clause that member states shall ensure that pecuniary sanctions of up to $2 \%$ of the total worldwide annual turnover of the service provider can be imposed. ${ }^{35}$ If accepted, such sanction could theoretically be imposed for refusal to provide data in case of a simple offence that fulfils the minimal thresholder of imprisonment, which would not be proportional sanction. Judicial authorities of the enforcing member state would eventually be involved in the process in cases where the service providers decide not to execute the issued order within the deadline or without providing reasons accepted by issuing authority. ${ }^{36}$ The proposed solution of the enforcement procedure by competent authority is similar to classical mutual recognition instruments. In addition, the enforcement authority might refuse to act upon request based on grounds listed in the proposed Regulation. ${ }^{37}$

\section{Inconsistency of proposed instrument with rule of law standards}

The proposed Regulation raised concerns among several groups of key stakeholders, including critical opinions expressed by EU bodies ${ }^{38}$ and association of legal professionals. ${ }^{39}$ Even the European Commission in the Explanatory Memorandum

34 Article 2(3).

35 Article 12 of the proposed Regulation, Council of the European Union, Brussels, 11 June 2019, 10206/19.

36 Article 14 of the proposed Regulation.

37 Article 14 (4)(5).

38 European Data Protection Board (EDPB), Opinion 23/2018 on Commission proposals on European Production and Preservation Orders for electronic evidence in criminal matters (Art. 70.1.b), adopted on 26 September 2018.

39 ECBA Opinion on European Commission Proposals for: (1) A Regulation of the European Parliament and of the Council on European Production and Preservation Orders for electronic evidence \& (2) a 
to the proposal recognizes that the use of the Production and Preservation Orders could potentially affect a number of fundamental rights, including the right to protection of personal data, the right to respect private and family life, the right to freedom of expression, the right of defense, the right to an effective remedy and to a fair trial. Although the proposed Regulation envisages situation when prior intervention of a judicial authority is obligatory, the proposed provisions do not offer guarantees that independent judicial scrutiny will be ensured systematically in the issuing country nor in the execution country. The involvement of public prosecutors, without judicial control, could raise issue of impartiality in decision making. As noted by the Venice Commission, in some countries a prosecutorial bias seems to lead to a quasi-automatic approval of all such request from the prosecutors, which can put in danger independence of the judiciary. ${ }^{40}$

Proposed solution on issuing and executing authority is not in line with the EU Court of Justice jurisprudence related to the mutual recognition instruments (Carrera, Stefan, 2020: 33). In 2019 the Court of Justice assessed that German public prosecutor offices could not be considered as judicial authority for the purpose of the issuing European Arrest Warrant. ${ }^{41}$ The Irish Supreme Court submitted the preliminary request which considered the execution of the three European Arrest Warrants issued prior to judgment for the purposes of conducting a criminal prosecution by two German public prosecutor offices. The Court of Justice held that the issuing authority in an European Arrest Warrant case "must be in a position to give assurance to the executing judicial authority that it acts independently in the execution of those of its responsibilities". ${ }^{42}$ The Court of Justice added that a clear sign of a lack of independence was the power of the Ministry of Justice to issue instructions to public prosecutors offices and directly influence on prosecutor in issuing a decision..$^{43}$ The Court of Justice requires from several EU countries to either align their public prosecution services with the judicial independence benchmarks or subject their decisions to the independent judicial oversight mechanisms. ${ }^{44}$

Directive of the European Parliament and of the Council laying down harmonized rules on the appointment of legal representatives for the purpose of gathering evidence in criminal proceedings.

40 European Commission for Democracy through Law (Venice Commission) (2011), "Report on European Standards as regards the Independence of the Judicial System: Part II - The Prosecution Service", 2011 Study no. 494/2008, Strasbourg.

41 Minister for Justice and Equality $v O G$ and PI, Joined Cases C-508/18 and C-82/19 PPU, ECLI:EU:C:2019:456.

42 Para 74.

43 Para 83.

44 Who qualifies as a 'judicial authority for the purposes of issuing a European Arrest Warrant?, (2018) Fair Trials, available at https://www.fairtrials.org/sites/default/files/publication_pdf/CJEU_27_ May_2019_cases_IP_LB_final.pdf 
The proposed Regulation is abandoning the approach of mutual recognition instruments that envisages judicial control in the executing state (Mitsilegas, 2018: 263), but foresees role of judicial authorities only in enforcing foreign authority order once when service provider failed to comply with it.

The lack of systematic judicial control of issued order by executing state could have impact on legal certainty and limits the exercise of right to effective legal remedy that is guaranteed by EU acquis to suspect and accused persons. When an order concerns a person who has residence in the executing state, the judicial authority in the executing state should conduct ex ante control which is in line with the principles of fair trial. Without the opportunity to seek remedies in the executing state, the risk exists of increasing appeals against companies who provided data through civil law. However, the civil law protection could not be accepted as effective legal remedy in criminal justice (Carrera, Stefan, Mitsilagis, 2020: 59).

Although the proposed Regulation have been presented as an instrument that intended to tackle serious crime and terrorism, the provision of the Regulation refers to the threshold of three years for Production orders, while for Preservation orders there is no such requirement. Expending the scope of Production and Preservation orders could be detrimental, since judicial authorities would need to review large numbers of orders.

The proposed definition of fines for non-compliance with order could have effect on protection of privacy. If proposed threshold for sanction of $2 \%$ of annual turnover would be accepted, the services provider could feel compelled to execute orders even when they should have done so.

According to the Explanatory Memorandum of the proposed Regulation, ${ }^{45}$ personal data covered by the instrument are protected and may be processed only in line with General Data Protection Regulation (GDPR) ${ }^{46}$ and the Data Protection Directive for Police and Criminal Justice Authorities ${ }^{47}$ Furthermore, article 8 of the EU Charter on fundamental rights applies to processing of personal data and although there is distinction between sensitive data that have additional protection, all private data should be protected in line with basic data protection standards.

45 Recital 20 of the proposed Regulation.

46 Regulation (EU) 2016/679 of the European Parliament and of the Council of 27 April 2016 on the protection of natural persons with regard to the processing of personal data and on the free movement of such data, and repealing Directive 95/46/EC (General Data Protection Regulation), OJ L 119, 4.5.2016, p. 1-88

47 Directive (EU) 2016/680 of the European Parliament and of the Council of 27 April 2016 on the protection of natural persons with regard to the processing of personal data by competent authorities for the purposes of the prevention, investigation, detection or prosecution of criminal offences or the execution of criminal penalties, and on the free movement of such data, and repealing Council Framework Decision 2008/977/JHA, OJ L 119, 4.5.2016, p. 89-131 
Based on this understanding it is not clear why the proposed Regulation is providing lower level of protection to subscriber and access data. (Carrera, Stefan, 2020: 51)

The proposed Regulation should be also assessed against the Court of Justice jurisprudence. The Court of Justice has ruled that when metadata, such as traffic and location data, could lead to establishing of profile of the individuals, such information is sensitive same as the actual content of communication, in relation to the right to privacy. ${ }^{48}$ (Corhay, 2021: 448)

The challenge caused by differentiation of data and level of protection becomes more problematic in relation to admissibility of those data as evidence across the EU member states. In some EU countries evidence collected according to the wrong procedure, without the required judicial validation, will still be admissible due to lack of EU legal framework of admissibility of evidence and different national regulation across the EU member states.

\section{Conclusions}

Development of IT technologies affected criminal justice systems and majority of evidence are in the electronic form by service providers that might have headquarter in another EU member state, or very often outside the EU. Access to those electronic evidence poses challenges for law enforcement and criminal investigation authorities. Traditional instruments of mutual legal assistance and mutual recognition have operational and technical shortcomings, however the proposed Regulation on Production Order and Preservation Order is not in line with EU rule of law standards.

To align proposed Regulation with the EU criminal justice standards, including protection of right of suspect and accused person, and data protection standards, it is necessary to envisage involvement of competent judicial authorities, both in issuing and executing country. Effective judicial oversight over the issuing and execution of production orders should be always ensured, regardless of type of data sought.

The scope of application of Production and Preservation orders should be limited to more serious crimes. The list of specific harmonized offences on which orders would be applicable could be drafted and annexed to the Regulation.

Furthermore, the proposed Regulation should include grounds for objection by service providers against a receive orders, including clarification when fundamental rights are under the risk. The sanctions for non-compliance should be

48 Tele2 Sverige AB v Post - och telestyrelsen and Secretary of State for the Home Department $v$ Tom Watson and Others Joined Cases C-203/15 and C-698/15, ECLI:EU:C:2016:970, para 27. 
reviewed to avoid situations that service providers due to the risk of high penalties disclose information even when fundamental rights are violated.

The proposed Regulation is attempt to mitigate risks that IT development put in front of criminal justice systems, but it cannot undermine the rule of law standards and fundamental right protection. Criticism of proposed instruments confirm shortcomings of the proposed Regulation, not only from the perspective of rights of suspect and accused person, but also from the position of service providers and judicial authorities. The way forward must include additional consultations and revision of the proposed document to ensure all standard and address the need to have efficient mutual recognition tool that will tackle electronic evidence.

\section{References}

- Carrera S., Stefan, M. (2020) Access to Data for Criminal Investigation Purposes in the EU. CEPS Paper in Liberty and Security in Europe, No. 2020-01. Brussels: CEPS.

- Carrera S., Mitsilegas, V., Stefan, M. (2021) Criminal Justice, Fundamental Rights and the Rule of Law in the Digital Age. Report of a CEPS and QMUL Task Force. Brussels: CEPS.

- Corhay, M. (2021) Private Life, Personal Data Protection and Role of Service Providers: The EU E-Evidence Proposal. European Papers, 6(1), pp. 441-471

- Daskal, J., (2015) The Un-Territoriality of Data. Yale Law Journal, 125(2), pp. J 326-398.

- Franssen, V. (2017) The Belgian Internet Investigatory Powers Act - A Model to Pursue at European Level? Europen Data Protection Law Review, 3(4), pp. 534-542. https://doi.org/10.21552/edpl/2017/4/18

- Herlin-Karnell, E. (2012) The Constitutional Dimension of European Criminal Law. Oxford: Hart Publishing.

- De Hert, P., Parlan, C., \& Thumfart, J. (2018) Legal Instruments used in courts regarding territoriality and cross-border production orders: From Yahoo Belgium to Microsoft Ireland. New Journal of European Criminal Law, 9(3), pp. 326-352. https://doi.org/10.1177/2032284418801562

- Klimek, L. (2017) Mutual Recognition of Judicial Decisions in European Criminal Law. Springer International Publishing

- Krishnamurthy, V. (2016) Cloudy with a Conflict of Laws: How Cloud Computing Has Disrupted the Mutual Legal Assistance Treaty System and Why It Matters. Berkman Klein Center Research Publication No. 2016-3. 
- Lenaerts, K. (2017), La Vie Après L'Avis: Exploring the Principle of Mutual Recognition (Yet Not Blind) Trust. Common Market Law Review, 54(3), pp. 805-840

- Mitsilegas, V. (2006) Trust-building measures in the European judicial area in criminal matters: issues of competence, legitimacy and inter-institutional balance, In: Balzaq, T, Carrera, S. (eds.) Security versus freedom? A challenge for Europe's future, Ashgate: Aldershot, pp. 280-289

- Mitsilegas, V. (2016) EU Criminal Law after Lisbon. Oxford: Hart Publishing

- Matić Bošković, M., Nenadić, S. (2021) Impact of COVID-19 Pandemic on Criminal Justice Systems across Europe. EU and Comparative Law Issues and Challenges Series (ECLIC), 5, pp. 263-290. https://doi.org/10.25234/ eclic/18307

- Mitsilegas, V. (2018), The privatisation of mutual trust in Europe's area of criminal justice: The case of e-evidence. Maastricht Journal of European and Comparative Law, 25(3), pp. 263-265. https://doi.org/10.1177/1023263X 18792240

- Stefan, M., González, G. (2018), Cross-border Access to Electronic Data through Judicial Cooperation in Criminal Matters: State of the art and latest developments in the EU and the US. CEPS Liberty and Security Series, Brussels: CEPS.

- Suominen, A. (2011) The Principle of Mutual Recognition in Cooperation in Criminal Matters. Intersentia.

- Tinoco-Pastrana, A. (2020) The Proposal on Electronic Evidence in the European Union, Eucrim, 1, pp. 46-50. https://doi.org/10.30709/eucrim-2020-004

- Tosza, S. (2020) All evidence is equal, but electronic evidence is more equal than anu other: The relationship between the European Investigation Order and the European Production Order. New Journal of European Criminal Law, 11(2), pp. 161-183. https://doi.org/10.1177/2032284420919802

- Tosza, S. (2021) Internet service providers as law enforcers and adjudicators - A public role of private actors. Computer Law and Security Review, 43, 105614. https://doi.org/10.1016/j.clsr.2021.105614

- Warken, C. (2018) Classification of Electronic Data for Criminal Law Purposes. Eucrim, pp. 226-234. https://doi.org/10.30709/eucrim-2018-023

- Willems, A. (2021) The Principle of Mutual Trust in EU Criminal Law. Oxford: Hart Publishing.

\section{EU Documents}

- Council Framework Decision 2002/584/JHA, of 13 June 202 on the European arrest warrant and the surrender procedures between Member States, OJ L190/1, p. 1-20. 
- Council Framework Decision 2009/829/JHA, of 23 October 2009 on the application, between Member States of the European Union, of the principle of mutual recognition to decisions on supervision measures as an alternative to provisional detention, OJ L 294/20, p. 226-246.

- Council Framework Decision 2005/214/JHA, of 24 February 2005 on the application of the principle of mutual recognition to financial penalties, OJ L 76/16, p. 16-30.

- Council Framework Decision 2008/947/JHA, of 27 November 2008 on the application of the principle of mutual recognition of judgements and probation decisions with a view to the supervision of probation measures and alternative sanctions, OJ L 337/102, p. 102-122.

- Council Framework Decision 2008/909/JHA, of 27 November 2008 on the application of the principle of mutual recognition to judgements in criminal matters imposing custodial sentences or measures involving deprivation of liberty for the purpose of their enforcement in the European Union, OJ L $327 / 27$, p. $27-46$.

- Directive 2014/41/EU, of 3 April 2014 regarding the European Investigation Order in criminal matters, OJ L 130, p. 1-36.

- Directive (EU) 2016/680 of the European Parliament and of the Council of 27 April 2016 on the protection of natural persons with regard to the processing of personal data by competent authorities for the purposes of the prevention, investigation, detection or prosecution of criminal offences or the execution of criminal penalties, and on the free movement of such data, and repealing Council Framework Decision 2008/977/JHA, OJ L 119, 4.5.2016, p. $89-131$

- Regulation (EU) 2016/679 of the European Parliament and of the Council of 27 April 2016 on the protection of natural persons with regard to the processing of personal data and on the free movement of such data, and repealing Directive 95/46/EC (General Data Protection Regulation), OJ L 119, 4.5.2016, p. $1-88$

- Regulation 2018/1805 of the European Parliament and of the Council of 14 November 2018 on the mutual recognition of freezing orders and confiscation orders, OJ L 303/1, p. 1-38.

- Proposal for a Directive of the European Parliament and of the Council laying down harmonized rules on the appointment of legal representatives for the purpose of gathering evidence in criminal proceedings, $\operatorname{COM}(2018) 226$ final.

- Proposal for a Regulation of the European Parliament and of the Council on European Production and Preservation Orders for electronic evidence in criminal matters, $\operatorname{COM}(2018) 225$ final. 
- Commission of the European Communities (2000) Mutual Recognition of Final Decisions in Criminal Matters, Communication from the Commission to the Council and the European Parliament, COM(1999) 495 final.

- European Council (1999) Presidency Conclusions, Tampere European Council 15th-16th October 1999, European Council.

- Commission Staff Working Document - Impact Assessment accompanying the Proposal for a Regulation on European Production and Preservation Orders for electronic evidence in criminal matters and the Proposal for a Directive laying down harmonised rules on the appointment of legal representatives for the purpose of gathering evidence in criminal proceedings, $\operatorname{SWD}(2018)$ 118, p. 14.

- Council Conclusions on the Joint Communication to the European Parliament and the Council: Resilience, Deterrence and Defence: Building strong cybersecurity for the EU, 14435/17,

- Communication from the Commission to the European Parliament, the European Council, the Council, the European Economic and Social Committee and the Committee of the Regions on the EU Security Union Strategy, $\mathrm{COM} / 2020 / 605$ final.

- Communication from the Commission to the European Parliament, the European Council, the Council, the European Economic and Social Committee and the Committee of the Regions - Digitalisation of justice in the European Union - A toolbox of opportunities, COM/2020/710 final.

- 2020 Rule of Law Report - Country chapter on rule of law situation in Italy, SWD(2020) 311 final.

- European e-Justice Portal, "Digital Tools in Member States".

- The Impact of COVID-19 on Judicial Cooperation in Criminal Matters Analysis of Eurojust's Casework, EUROJUST, 2021.

- Non-paper: Progress Report following the Conclusions of the Council of the European Union on Improving Criminal Justice in Cyberspace, 2 December 2016, 15072/16.

Caselaw

- Advocaten voor de Wereld VZWv Leden van de Ministerraad, Case C-303/05, [ECLI:EU:C:2007:261].

- Google Spain SL and Google Inc. v. Agencia Española de Protección de Datos (AEPD) and Mario Costeja González, Case C-131/12, [ECLI:EU:C:2014:317].

- Minister for Justice and Equality v OG and PI, Joined Cases C-508/18 and C-82/19 PPU, [ECLI:EU:C:2019:456].

- PPU Minister for Justice and Equality v LM, Case C-216/18 [ECLI:EU:C: 2018:586]. 
- Tele2 Sverige AB v Post - och telestyrelsen and Secretary of State for the Home Department $v$ Tom Watson and Others Joined Cases C-203/15 and C-698/15, [ECLI:EU:C:2016:970].

- Yahoo! Inc. v Belgium case, Hof van Cassatie of Belgium, 1 December 2015, case P.13.2082.N. 